\title{
Alegoria e história da literatura como provocação à teoria literária.
}

\section{Anderson Borges (UFMG)}

Resumo: Neste texto aproximo as noções de alegoria e historicidade presentes, respectivamente, no estudo do Trauerspiel feito por Walter Benjamin e na estética da recepção de Hans Robert Jauss, enfocando o aspecto crítico e fundamental da leitura. Circunscrevendo como corpus de análise alguns excertos extraídos de Origem do drama barroco alemão, bem como da História da literatura como provocação à teoria literária, reflito sobre a relação entre crítica e historicidade apresentada pelos autores em questão.

Palavras-chave: alegoria; historicidade; crítica.

Considerando que para Walter Benjamin, a alegoria constitui a chave interpretativa do barroco alemão, e que para Hans Robert Jauss, um dos principais nomes da chamada estética da recepção, a história da literatura deve ser considerada de uma forma dinâmica - a partir de cortes sincrônicos e de articulações promovidas pelo leitor - é possível pensar que em ambos os autores a leitura exerce um importante papel na construção teórica, até mesmo fundamental na relação entre crítica e historicidade. Neste texto a idéia de atualização interpretativa - em que a subjetividade do leitor/crítico é valorizada - encontrada no estudo do Trauerspiel (traduzido para o português como "drama barroco") feito por Benjamin será arrolada à provocativa teoria literária jaussiana tendo em vista uma crítica possibilitada ao constatar historicidade.

O pensador berlinense advoga pela autenticidade da expressão artística alegórica, demonstrando que a abertura interpretativa possibilita a atualização mediante a leitura. Como se sabe, a afirmação de que uma obra se constitui de ruínas abriu portas para a interpretação alegórica. Seu estudo em torno do drama barroco alemão foi a primeira mostra disso. Embora não seja o foco da presente análise, vale lembrar que mais tarde nas reflexões benjaminianas sobre a literatura de Baudelaire e dos vanguardistas a alegoria pôde também ser vislumbrada em suas leituras e, até mesmo, como técnica para efetuar suas análises.

Jeanne Marie Gagnebin chama atenção que já em "O Narrador", texto escrito em 1936, Walter Benjamin anuncia uma teoria antecipada da obra aberta, lembrando a teorização a esse respeito feita algum tempo depois por Umberto Eco. Além disso, ela reflete sobre a possibilidade de que "também na doutrina benjaminiana da alegoria, a profusão do sentido, ou, antes, dos sentidos, vem ao contrário, de seu não-acabamento essencial"1. Não há dúvidas de que a alegoria, nesse sentido, pode ser relacionada à resposta do leitor teorizada por Jauss, conforme aprofundo a esse respeito nas páginas seguintes.

Não é preciso reiterar de forma exaustiva que ler constitui a chave mestra para a estética da recepção, tendo em vista tanto a fenomenologia de Wolfgang Iser quanto a hermenêutica de Hans Robert Jauss. Sucessor à explosão de sentidos anunciada pela alegoria benjaminiana, Jauss defende a concepção de uma história da literatura

Cadernos Benjaminianos, n. 3, Belo Horizonte, jan.-jun. 2011, p.1-13. 
diferente daquela tradicionalmente concebida até então. No texto História da literatura como provocação à crítica literária, ele comenta que "a historicidade da literatura" deve ser estabelecida "no experimentar dinâmico da obra literária por parte de seus leitores"2. Segundo essa perspectiva, à chamada "superação da contemplação diacrônica" por ele anunciada, deriva a possibilidade de serem articulados historicamente vários cortes sincrônicos efetivando, desse modo, uma mudança estrutural na história da literatura.

Retomando Gagnebin, desta vez considerando a conclusão de seu texto "Nas fontes paradoxais da crítica literária. Walter Benjamin relê os românticos de Iena" (2007), a autora propõe que o papel da crítica dos nossos dias - herdeira do romantismo alemão -, talvez, seja, seguindo as reflexões benjaminianas, refletir sobre a relação entre crítica e historicidade. Na esteira dessa hipótese, este ensaio assume o papel de prolongar questionamentos decorrentes do estudo benjaminiano relacionado ao drama barroco alemão que discute esses dois pontos, aproximando-o da perspectiva histórico-recepcional proposta por Hans Robert Jauss.

Divido este trabalho nas seguintes seções, procurando contextualizar as teorizações dos dois autores, para finalmente abordar ambas as teorias vislumbrando certas semelhanças: 1. A crítica benjaminiana do drama barroco alemão; 2 . Teorizações jaussianas sobre a dimensão histórica da literatura; 3. A historicidade da literatura em Benjamin e Jauss; além desta breve introdução e da conclusão do texto.

\section{A crítica benjaminiana do drama barroco alemão}

Para falar da crítica benjaminiana do barroco alemão, é necessário inicialmente uma breve contextualização do percuso teórico rumo à valorização da alegoria como forma adotada na literatura do século XVII. Ao estudar o Trauerspiel alemão, Walter Benjamin desbravou um domínio da literatura alemã até então inexplorado, como menciona Max Bense ${ }^{3}$. De um modo geral, o interesse pelo barroco aumentou logo após a primeira guerra mundial com a publicação de antologias sobre a literatura barroca, o que influenciou fortemente o expressionismo. Nas "Questões introdutórias de crítica do conhecimento", Benjamin cita a perspectiva do historiador literário Victor Manheimer asseverando certa similaridade entre o barroco e a literatura de seu tempo ${ }^{4}$.

Sobre a recepção da estética barroca no início do século $\mathrm{XX}$, vale a pena considerar uma possível explicação para sua valorização tardia. Se de um lado a circulação de seletas barrocas exerceu forte influência na literatura expressionista, não seria possível pensar o caminho inverso? Ou seja, o então recente expressionismo teria suscitado um interesse pelo barroco - ilustrando, de certo modo, um comentário feito por Jauss, de que a história da literatura é construída de modo dinâmico pela experiência literária do leitor e que por isso uma obra contemporânea pode alterar a maneira de ler uma antiga.

Desfazendo-se do ponto de vista classicista, segundo o qual a forma alegórica era vista como uma mera forma de ilustração, Benjamin propõe, então, teorizar sobre o valor da alegoria enquanto expressão, como a linguagem e a escrita, reconhecendo-a como "lei estilística dominante do alto Barroco".

Um importante ponto por ele tratado em sua argumentação sobre a forma alegórica é a comparação feita entre alegoria e símbolo. Primeiramente ele utiliza Friedrich Creuzer como referência teórica, para o qual alegoria significa "um conceito geral ou uma idéia", ao passo que o símbolo é "a idéia em sua forma 
sensível, corpórea"6. Em seguida, Benjamin critica a distorção do conceito de símbolo feita pelos românticos, considerando sua ocorrência quando "numa obra de arte a 'manifestação' de uma 'idéia' é caracterizada como 'símbolo"," . Mais à frente, ele menciona uma carta de Goethe, em que este, comparando alegoria e símbolo, ressalta a superioridade deste último.

Existe uma grande diferença, para o poeta, entre o particular a partir do universal, e ver no particular o universal. Ao primeiro tipo pertence a alegoria, em que o particular só vale como exemplo do universal. O segundo tipo corresponde à verdadeira natureza da poesia: ela exprime um particular, sem pensar no universal, nem a ele aludir. Mas quem capta esse particular em toda a sua vitalidade capta ao mesmo tempo o universal, sem dar-se conta disso, ou dando conta muito mais $\operatorname{tarde}^{8}$.

Em oposição ao pensamento de Goethe, Benjamin considera como a alegoria destrói a totalidade ilusória do símbolo, já que este possui um caráter instantâneo, enquanto aquela, por ter um caráter sucessivo, realça a impossibilidade de um sentido eterno a partir de uma dialética assentada no tempo. Ao contrário da rigidez estabelecida por um símbolo, a alegoria permite ampliar o espectro de significados.

Assim, tendo em vista a ação do tempo, podemos dizer que o sentido em relação à alegoria não nasce apenas da vida como também pode nascer da morte. Jeanne Marie Gagnebin sintetizou muito bem a importância da alegoria para construção de significado.

A alegoria cava um túmulo tríplice: o do sujeito clássico que podia ainda afirmar uma identidade coerente de si mesmo, e que, agora, vacila e se desfaz; o dos objetos que não são mais os depositários da estabilidade, mas se decompõem em fragmentos; enfim, o do processo mesmo de significação, pois o sentido surge da corrosão dos laços vivos e matérias entre as coisas 9 .

A interpretação alegórica expõe, portanto, a ligação entre significação e historicidade, revelando a face da história. "A história em tudo o que nela desde o início é prematuro, sofrido e malogrado, se exprime num rosto - não, numa caveira" $" 10$.

Assim, já em Origem do drama barroco alemão, Benjamin reunia elementos para a construção de uma filosofia de história - que deveria se ocupar dos oprimidos como ele menciona anos depois em suas "Teses sobre o conceito da história" construída por fragmentos, e saturada de agoras fazendo oposição à linearidade e ao objetivismo característicos do historicismo. Mas esse é um assunto com o qual não me ocupo neste texto.

O que me interessa aqui é perceber como o "eterno deperecimento" característico do barroco possibilita à análise crítica reconhecer a ação corrosiva do tempo. A interpretação alegórica de uma obra a partir de suas ruínas aponta para a relação cabal entre significado e historicidade. Considerando a idéia de finitude presente na estética barroca, é possível dizer que ela está inserida na própria linguagem, já que a alegoria destruiu a noção de um significado definitivo e instaurou a possibilidade de reinterpretar. Afinal de contas, a alegoria é comparada por Benjamin a ruínas.

Cadernos Benjaminianos, n. 3, Belo Horizonte, jan.-jun. 2011, p.1-13. 
A gênese para entender a noção dessa destruição está na descontinuidade entre natureza e história empreendida no barroco. Foi o temperamento melancólico barroco que provocou o deslocamento do contexto natural das coisas. Nas palavras do pensador berlinense, "o olhar profundo da melancolia transforma objetos e obras em excitante escrita" $"$. Benjamin aponta para o fato de que o leitor pode conferir um novo significado ao que lê, pois no drama barroco a alegoria possui um "caráter ontológico" e exige em cada palavra uma decisão para constituir um significado.

Em se tratando da noção de crítica, a idéia de que "a crítica é a mortificação das obras" quer dizer "uma instalação do saber nas [obras] que estão mortas" 12 é de suma importância. O crítico tem a capacidade de despertar "a beleza adormecida na obra”. Reconhecendo a temporalidade em torno dela, ele não lamenta as ruínas que a constituem. Ao contrário, as afirma e tornando-as objeto de sua meditação. Com esse modelo de interpretação, ele desmancha o legado romântico de infinita potencialidade de uma obra de arte. Logo, Benjamin ao lado da literatura moderna também possui uma consciência aguda do tempo e faz uso dela enquanto crítico literário.

É valioso lembrar que a interpretação alegórica forneceu-lhe elementos para estudar a história de uma forma muito singular, relacionando-a à literatura, ou ainda, à própria história, meditando, a partir das ruínas, sobre novas perspectivas, tal qual vemos em seu Passagen-Werk. Ralf Konersmann propõe que a crítica benjaminiana se sustenta numa espécie de leitura do mundo, a fim de interpretá-10 ${ }^{13}$.

Vale a pena relacionar o final desse estudo acerca do barroco com a emblemática figura do Anjo olhando para trás, para o qual a natureza histórica se revela um "amontoado de escombros", como história do sofrimento dos homens. O quadro de Klee chamado "Angelus Novus", a que Benjamin faz referência em sua nona tese em "Sobre o conceito da história", anuncia uma visão alegórica da história afirmando o passado como a ruína de edifícios destruídos (a despeito de uma seqüência de acontecimentos). Uma visão oposta à clássica filosofia da história no século XIX, cujas características eram as perspectivas progressista e historicista.

Tomando o olhar do anjo para trás como uma reflexão em torno do plano estético - uma vez que não objetivo estudar a historiografia benjaminiana, embora ela possua uma estreita relação com a interpretação alegórica -, é possível pensar novamente a alegoria valorizada por Benjamin como forma interpretativa. O "eterno deperecimento", característico do barroco, é visto também na imagem da modernidade, anunciando as catástrofes do presente e, do amargo futuro que seria anunciado poucos anos depois com o desfecho da segunda grande guerra. Essa imagem de ruínas, semelhante à escrita barroca, anuncia uma vez mais a ação corrosiva do tempo. O discurso alegórico desmascara a história, conforme elucida Bernd Witte em seu estudo sobre a escrita e o escrito benjaminiano.

Retomando o caráter destrutivo característico do barroco, Benjamin chama atenção para o fato de que a função dos livros escritos naquela época não era difundir-se no futuro, desde o início, aquelas obras "já estavam predestinadas à destruição crítica, que o tempo sobre elas exerceu"14.

Num outro momento, Benjamin afirma a natureza como grande mestra do poeta do período barroco, vista sob o ponto de vista melancólico. "Para eles [os poetas], a natureza é o eternamente efêmero, e só nesse efêmero o olhar saturnino daquelas gerações reconhecia a história" 15 . Desse modo, a história penetrou o palco e somouse ainda à predileção barroca por tudo o que mostra a morte na obra. A distância temporal revelou, então, como mencionado anteriormente, uma paisagem de ruínas,

Cadernos Benjaminianos, n. 3, Belo Horizonte, jan.-jun. 2011, p.1-13. 
anunciando uma tarefa reservada à crítica: reconhecer a ação do tempo e da história, compreendendo sua atuação mesmo nas mais belas obras.

Como mencionado anteriormente, a renovação do interesse pelo Barroco na Alemanha no início do século XX correspondeu, para Benjamin, a um período de "decadência produtiva". A matéria para a criação barroca, conforme ele afirma, constituiu também a literatura expressionista ${ }^{16}$.

O início da produtividade literária da excessiva maturação das coisas, ou ainda, do negativo e da morte, nas análises benjaminianas, aconteceu no barroco. Sérgio Paulo Rouanet, tradutor e estudioso do autor no Brasil, comenta que a alegoria tem a morte como estrutura e como conteúdo ${ }^{17}$. Naturalmente, o barroco, como bem se sabe, evidenciou essa particularidade.

Ora, retomando importantes conceitos benjaminianos relacionados à distância do drama barroco alemão - conseqüente dessa corrosão antes mencionada - que motivam a interpretação alegórica, é necessário considerar a composição de uma obra em suas duas instâncias, como bem aponta Jeanne Marie Gagnebin.

Deve-se levar até o fim este processo de decomposição entre o 'teor coisal' (Sachgehalt) e "teor de verdade" (Wahrheitsgehalt), reservando ao comentário a descrição detalhada destes acessórios essenciais que fazem a materialidade, a historicidade e a caducidade da obra, à crítica o cuidado do "enigma", "daquilo que é vivo", a saber, que o "teor de verdade" não desapareça totalmente com o desmembramento do "teor coisal"

Dessa forma, cabe à crítica demonstrar o "teor de verdade" de uma obra. A hermenêutica benjaminiana noticia esse ponto a partir da investigação histórica e da constatação de que a alegoria pode desvendar o "enigma". Novamente lembrando as palavras de Benjamin, o destino que aguardava essas obras - do barroco alemão era a destruição, decorrente do tempo, restando ao crítico as ruínas da obra. O crítico, aqui considerado leitor, então, debatendo-se com o tempo, atualiza uma interpretação alegórica que, em última instância, não possui um sentido último.

Nesse contexto, o trabalho da produção de sentido nasce dos restos do objeto, ou até mesmo dos rastros que sua ausência deixou. Exatamente aí está a importância da alegoria como construção de significados que foram, ou serão, destruídos pelo tempo. Essa interpretação suscita o reconhecimento do tempo e da historicidade.

Aqui, o crítico contribui declaradamente com sua subjetividade. Talvez por isso, Bernd Witte, considerando a técnica alegórica e o procedimento metodológico da ensaística de Benjamin, afirme que "a escrita é linguagem da morte e dos mortos"19. A morte, tendo em vista a inexorabilidade do tempo a que todas as coisas, inclusive as mais belas obras, estão fadadas, é a origem da significação da linguagem.

Como bem se sabe, para Benjamin a estrutura de significantes pode ser constantemente renovada a partir de novas constelações. É possível até mesmo questionar se sua maneira de criticar, muitas vezes, constituída, ela mesma, de alegorias deriva dessa compreensão em torno do tempo e da historicidade que envolve todas as coisas.

A aproximação de opostos em sua crítica permitiu a Benjamin, por um lado, estudar um objeto por uma contemplação distanciada, organizada por um emaranhado de citações (influenciado pelo romantismo ienense) e por outro lado, constituir um teor fragmentado oriundo de pensar a destruição, o que lhe permitiu, muitas vezes, escrever alegorias em seus ensaios, tornando possível que alguns

Cadernos Benjaminianos, n. 3, Belo Horizonte, jan.-jun. 2011, p.1-13. 
comentadores, como é o caso do português João Barrento, afirmassem que Walter Benjamin eventualmente mimetize o objeto de sua reflexão. A forma fragmentada da escrita benjaminiana pode beneficiar a aproximação e o afastamento de idéias diversas favorecendo, junto à alegoria que constitui sua crítica, uma multiplicidade de leituras.

Walter Benjamin, utilizando em sua própria escrita uma imagem alegórica, considera que "a subjetividade, caindo como um anjo no abismo, é trazida de volta pelas alegorias" 20 . Aqui interpreto essa subjetividade como a voz dada ao leitor, o que me permite evocar a estética da recepção.

Morte, destruição, ruínas são palavras muito caras à crítica benjaminiana do barroco alemão. Ao contrário da perspectiva historicista que estabelecia a objetividade como constituinte de seu modus operandi, o crítico, paralelamente ao historiador da literatura presente no pensamento de Hans Robert Jauss, se faz leitor e torna possível, dessa forma sua subjetividade, ou ainda, sua experiência literária, integrar sua análise.

\section{Teorizações jaussianas sobre a dimensão histórica da literatura}

Hans Robert Jauss com suas teorizações pretende dar um passo além das escolas formalista e marxista, uma vez que a querela entre esses dois métodos deixou de lado o problema da história da literatura. A estética da recepção jaussiana procura justamente "superar o abismo entre literatura e história, entre o conhecimento histórico e estético" por eles deixado ${ }^{21}$.

O formalismo inicialmente renunciou de modo deliberado a um conhecimento histórico em relação à literatura. A obra literária deveria ser contemplada pelo seu valor estético fundamentado unicamente na linguagem poética. Esta deveria ser confrontada à linguagem prática e feita a diferenciação, haveria uma "percepção artística". O anseio formalista, de natureza imanente, era desvendar o procedimento adotado na obra.

Para Jauss, o aspecto positivo dos estudos dos formalistas foi a transformação da crítica de arte num método racional. Mais tarde surgiu o reaparecimento da historicidade da literatura no formalismo a partir do qual era necessário repensar, não somente de forma sincrônica, mas também considerando os princípios da diacronia, o método formalista. Vítor Chklovski e Iúri Tynianov, dois importantes nomes dessa escola crítica citados por Jauss, consideravam que em toda época existem simultaneamente várias escolas literárias.

Embora os formalistas concentrassem seus estudos referentes a diacronia à noção de "compreender uma obra em sua história" considerando a idéia de evolução literária, isso não significava o mesmo que "contemplá-la na história"22. A estética da recepção foi responsável por esse último passo, anuncia Jauss.

Conforme já se sabe, a relação entre literatura e sociedade, em que a primeira anuncia o reflexo da segunda, é a base principal da história literária marxista. Mesmo assim, Jauss ressalta que nem todos os gêneros possuem uma "força testemunhal" em relação à "lembrança dos motivos constitutivos da sociedade". Além disso, a historiografia literária marxista não consegue abarcar a "heterogeneidade do simultâneo". Conservando a idéia de relacionar a importância de uma obra ao seu valor testemunhal relacionado ao processo social, na perspectiva jaussiana a tendência marxista permaneceu vinculada a uma estética classicista ${ }^{23}$.

Cadernos Benjaminianos, n. 3, Belo Horizonte, jan.-jun. 2011, p.1-13. 
Percebendo a lacuna deixada de um lado pelo formalismo - que embora tivessem considerado a evolução literária e o caráter sistemático constitutivo de cada momento, tendo apresentado a história da literatura como uma sucessão de sistemas estético-formais - e de outro pelo marxismo - cuja "teoria do reflexo" contempla a relação entre literatura e sociedade apenas no âmbito da representação -, a perspectiva jaussiana anuncia que a historicidade da literatura se encontra no experimentar dinâmico da obra literária por parte dos leitores (tendo em vista os três aspectos da historicidade, sobre os quais escrevo a seguir).

Dessa maneira, a relação entre literatura e história é estabelecida de modo que a autonomia do caráter artístico não é submetida à função meramente mimética e ilustrativa, respondendo à questão colocada no desfecho da quarta tese de seu texto A história da literatura como provocação à teoria literária.

Jauss concentra seus estudos em torno da literatura na dimensão da recepção e do efeito considerando a figura do leitor, indispensável tanto para o conhecimento estético - estabelecido pela avaliação feita a partir da leitura, bem como mediante comparações com outras obras já lidas - quanto para o histórico - em que "numa cadeia de recepções", a compreensão dos primeiros leitores tem continuidade e podem se enriquecer com as seguintes gerações decidindo, assim, o significado histórico de uma obra. Ora, o fio que liga o fenômeno passado à experiência presente é, então, reatado. Aqui é possível visualizar os argumentos utilizados por Jauss para a construção de uma história da literatura dinâmica.

Primeiramente, o historiador literário deve fazer-se, ele mesmo, leitor e, levando em consideração seu próprio juízo, é preciso, então, colocar-se na história estabelecida por leitores. A renovação da história da literatura estabelece com o leitor uma relação dialógica. Jauss compreende que "a história da literatura é um processo de recepção e produção estética que se realiza na atualização dos textos literários por parte do leitor que os recebe, do escritor, que se faz novamente produtor, e do crítico, que sobre elas reflete" 24 .

$\mathrm{O}$ acontecimento literário produz um efeito quando há leitores que experienciam obras passadas. Assim, a literatura enquanto "acontecimento" é produzida no horizonte de expectativas dos leitores. Este se define como resultado do conhecimento prévio do gênero, da forma. É o leitor quem estabelece ou modifica o chamado horizonte de expectativas literárias e, desse modo, escreve uma história da literatura.

Para Jauss, retomando o ponto de vista de Hans Georg Gadamer, a "história dos efeitos" (Wirkungsgeschichte) enreda a "consciência histórica" criticando de forma contundente a crença de que é possível obter o sentido "atemporalmente verdadeiro" - empregando o termo jaussiano - de uma poesia única e exclusivamente a partir de uma imersão no texto, sem levar em consideração a recepção histórica estabelecida por predecessores.

É exatamente em Gadamer que Jauss busca a dimensão produtiva da compreensão, entendida como "penetração num acontecer da tradição no qual passado e presente mediavam-se continuamente" 25 . Tal compreensão desempenha papel cabal no projeto estético-recepcional da história da literatura, em que a historicidade é apreendida em três aspectos: diacronicamente, sincronicamente e aqui se encontra a provocativa novidade trazida pela teorização jaussiana - segundo a relação entre a história da literatura e a literatura na história.

A feição diacrônica da historicidade da literatura se baseia naturalmente na inserção de uma determinada obra em sua "série literária", tornando possível o

Cadernos Benjaminianos, n. 3, Belo Horizonte, jan.-jun. 2011, p.1-13. 
conhecimento do contexto - aqui entendendo este termo no sentido de experiência literária, seguindo o raciocínio proposto por Jauss.

O aspecto sincrônico possibilita, por sua vez, averiguar a multiplicidade heterogênea anunciada num mesmo momento. Assim, a variação de formas em obras contemporâneas pode ser vista através dos cortes sincrônicos, revelando o desenvolvimento da literatura de uma determinada época. Trata-se de contemplar não apenas a sucessão de sistemas, mas também a simultaneidade de eventos, ou ainda pontos de interseção. Estes possibilitam a apresentação da literatura que articula "historicamente o caráter processual da 'evolução literária', em suas cesuras entre uma época e outra" ${ }^{26}$. Citando Jauss, "a historicidade da literatura revela-se justamente nos pontos de interseção entre diacronia e sincronia"27.

Finalmente, a literatura deve ser posta ao lado da história geral, permitindo assim verificar a formação de entendimento do mundo a partir da experiência literária do leitor. Aqui, Jauss comenta a partir do caso de Madame Bovary de Flaubert, como uma nova forma estética pode produzir também "conseqüências morais". Dizendo de outra maneira, como a leitura pode provocar no leitor o questionamento de ordens sancionadas por instituições sociais e/ou religiosas. Na perspectiva jaussiana no desfecho do texto de que me sirvo neste ensaio, "conclui-se que se deve buscar a contribuição específica da literatura para a vida social precisamente onde a literatura não se esgota na função de uma arte da representação,"28

A solução para a lacuna deixada pelo estruturalismo e pelo formalismo, recapitulando o que foi dito no início desta seção, acontece quando a literatura é dimensionada em sua função constitutiva da sociedade - novamente empregando os termos escolhidos pelo autor. Para Jauss, a finalidade de se estudar literatura, ou talvez possamos dizer, a tarefa do crítico literário é vislumbrar a formação do entendimento do mundo a partir da realização e da experiência literária. Aparentemente Walter Benjamin em seu estudo sobre o drama barroco alemão alcançou este fim, ao interpretar o teatro barroco como alegoria da história.

\section{A historicidade da literatura em Benjamin e Jauss}

A alegoria como forma interpretativa do Trauerspiel alemão anuncia, como já visto, o triunfo da subjetividade e lembra o terceiro aspecto da história da literatura formulado em A história da literatura como provocação à teoria literária. Retomando o argumento utilizado por Jauss, a história da literatura, deve ser considerada uma história particular e assim relacionada à história geral tendo em vista as implicações da experiência literária na vida prática. Em outras palavras, a literatura deve ser vista, além de diacrônica e sincronicamente, em sua relação com a formação do entendimento do mundo que o leitor possui.

Ao que parece, o dinamismo da história da literatura feita pelo leitor pode ser vislumbrado em A Origem do drama barroco alemão, publicado em 1928 lembrando que o drama barroco alemão, desde seu surgimento no século XVII, foi deixado às margens pela crítica durante quase trezentos anos e só no começo do século XX, houve um interesse pela estética barroca. A publicação de antologias de autores daquele período remoto coincidiu com o surgimento do expressionismo. Não se sabe de forma absoluta, mas é possível especular se o interesse pelo então esquecido barroco tenha surgido influenciado pela atmosfera expressionista afetada pelo pós-primeira guerra.

Cadernos Benjaminianos, n. 3, Belo Horizonte, jan.-jun. 2011, p.1-13. 
O próprio Benjamin no prefácio ao livro sobre o drama barroco chama atenção para as semelhanças entre os dois períodos, distantes em dois séculos e próximos no pessimismo e algumas vezes até mesmo na dimensão da linguagem.

É admissível até mesmo apostar na tese de que o expressionismo tornou possível ler o barroco alemão, reiterando o ponto de vista jaussiano de que pode acontecer de uma determinada obra ou, nesse caso, um conjunto de obras não ser valorizado pelo público imediatamente após seu surgimento. No entanto, uma mudança no horizonte de expectativa e, desse modo, o aparecimento de uma nova estética pode modificar a maneira do leitor receber uma obra antiga. Isso porque a leitura de obras do presente que de alguma forma se aproximem esteticamente com o passado pode alterar a forma de ler aquelas obras escritas séculos anteriores.

Perseguindo a seguinte cadeia de pensamento percebe-se como o barroco foi no princípio do século XX valorizado. Como bem comenta o teórico da alegoria, a forma tosca do drama barroco confrontava o teatro grego e assumia, assim, a alcunha de "repetição distorcida" da tragédia grega. Para Benjamin, a influência aristotélica se mostra irrelevante; o conteúdo mais autêntico do drama barroco é "a própria vida histórica, como aquela época a concebia" ${ }^{29}$ se distinguindo, assim, da tragédia, cujo objeto era o mito.

Benjamin advoga pela independência do drama barroco em relação à tragédia grega. O Trauerspiel é visto como uma forma natural, uma superação de formas antigas. Citando novamente o autor comentando a relação dos dois modelos de drama, "a tragédia antiga é uma escrava acorrentada ao carro triunfal do Barroco"30.

A característica que mais saltou aos olhos do crítico foi a alegoria. Esta não gozou de prestígio no meio crítico - lembrando o anteriormente citado exemplo de Goethe; a ele soma-se a valorização do símbolo efetuada pelo romantismo. Já no século XIX, Baudelaire elege a alegoria como constituinte de sua ars poetica. Aos poucos o negativo, a morte, as ruínas - imagens freqüentes no barroco - foram ganhando espaço na literatura. Enfim, a Europa assistiu o nascimento do expressionismo.

$\mathrm{Na}$ perspectiva benjaminiana, ambas as criações artísticas - expressionismo e o barroco - marcam um querer artístico, a despeito de um fazer artístico, pois, segundo ele, "é o que sempre ocorre nas chamadas épocas de decadência"31.

Conforme comentei no item dois deste mesmo texto, para Jauss, a história da literatura não é compreendida como uma sucessão de sistemas, ou seja, a historicidade não é uma conseqüência da mera conexão dos "fatos literários". Ela é fruto da experiência dinâmica do leitor. A releitura do passado se dá a partir da "fusão de horizontes". A valorização tardia do barroco demonstra esse dinamismo de que fala Jauss.

A mudança de "horizonte de expectativas" demonstra a possibilidade de uma forma artística discordante da demanda estabelecida difundir-se, então, entre os leitores. Walter Benjamin ao comentar sobre o interesse pelo período barroco mais de dois séculos depois demonstra como o expressionismo chamou atenção para o barroco revelando semelhanças estéticas e temáticas com o período remoto demonstrando como a percepção atual altera a recepção de uma obra literária até então incompreendida ou renegada ao esquecimento.

Ao argumentar sobre a concepção do homem naquele período, Benjamin exprime enquanto crítico e leitor do Trauerspiel a relação existente entre literatura e história. A literatura não é vista nesse caso como representação mimética da realidade social, nem são usados elementos que denunciem transformações sociais. Diferentemente do que foi feito no texto "Paris capital do século XIX", Benjamin não lança mão de

Cadernos Benjaminianos, n. 3, Belo Horizonte, jan.-jun. 2011, p.1-13. 
uma crítica sociológica. No caso da análise acerca do drama barroco, a alegoria manifesta o entendimento do mundo que o homem daquele tempo tinha. Uma visão imanentista refletindo os apelos do contexto da renascença e da contrareforma, lembrando que o drama barroco é marcado pelo luteranismo e pela melancolia.

"O homem religioso do Barroco adere (...) ao mundo (...) porque se sente arrastado com ele em direção a uma catarata"32. "Uma dinâmica que junta e exalta todas as coisas terrenas" ${ }^{33}$ confere ao drama barroco sua imanência. Há uma secularização do teatro dos mistérios e uma solução profana em detrimento de uma religiosa.

Explicando o termo "origem" (Ursprung) do título de seu livro, Benjamin traz a tona a idéia de historicidade: “A origem (...) não se destaca dos fatos, mas se relaciona com sua pré e pós-história" ${ }^{34}$. Essa explicação pode ser relacionada ao dinamismo que deve constituir a história da literatura proposto por Jauss. Novamente citando a perspectiva da estética da recepção jaussiana, a historicidade da literatura se compõe pela experiência do leitor.

O significado do texto para o leitor contemporâneo e o processo histórico pelo qual o texto é recebido nos tempos diversos são dois pontos de encontro da interpretação alegórica - renovada pela experiência individual da leitura e alimentada por uma tradição interpretativa de leitores e críticos precedentes - e da história da literatura - dinâmica e passível de novas articulações.

\section{Conclusão}

Dentre as semelhanças nas teorias dos dois autores, me dediquei a investigar o papel e o alcance da leitura relacionada às noções de crítica e historicidade. De Benjamin foi apresentada a alegoria como forma interpretativa do drama barroco alemão. Em Jauss busquei a novidade por ele teorizada em relação à história da literatura valorizando o dinamismo das articulações e sua feição constitutiva da sociedade. Como evidenciado, o estudo benjaminiano revela o crítico enquanto leitor, tal qual mencionado por Jauss em sua A história da literatura como provocação à teoria literária.

Benjamin, ao colocar-se enquanto crítico e leitor do Trauerspiel alemão, de certo modo, antecipa os dizeres de Jauss. A atualização posta em prática na interpretação alegórica é semelhante àquela praticada pelo leitor. Em outras palavras, a constatação do triunfo da subjetividade anuncia, paralelamente à perspectiva jaussiana, que a historicidade da literatura repousa no experimentar dinâmico da obra literária por parte dos leitores, a partir de sucessivas e contínuas leituras. Ler constitui uma atividade ativamente produtiva.

Diante desses dois importantes nomes da crítica do século XX, resta reconhecer há ainda reticênicas decorrentes de suas reflexões. Reconhecer, afinal, que há muito fio para tecer mais texto.

Abstract: In this text I put closer the notions of allegory and historicity present respectively in Walter Benjamin's study on the Trauerspiel and in the Hans Robert Jauss' aesthetics of reception, focusing the critical and fundamental aspect of reading. Circumscribing as corpus of analysis some excerpts of The Origen of the German Tragic Drama, so as of "Literary History as a Challenge 
to Literary Theory", I reflect on the relation between criticism and historicity presented by both authors in question.

Keywords: allegory; historicity; criticism.

\section{Referências Bibliográficas}

BARRENTO, João. Ler o que não foi escrito. Conversa inacabada entre Walter Benjamin e Paul Celan. Lisboa: Cotovia, 2005.

BENJAMIN, Walter. A origem do drama barroco alemão. Trad. Sérgio Paulo Rouanet, São Paulo: Brasiliense, 1984.

O narrador. Considerações sobre a obra de Nikolai Leskov. In: BENJAMIN, Walter. Magia e técnica, arte e politica: ensaios sobre literatura e história da cultura. 7. ed., trad. Sérgio Paulo Rouanet, São Paulo: Brasiliense, 1994, p. 197-221. (Obras escolhidas; v. 1)

Sobre o conceito da História. In: BENJAMIN, Walter. Magia e técnica, arte e política: ensaios sobre literatura e história da cultura. 7. ed., trad. Sérgio Paulo Rouanet, São Paulo: Brasiliense, 1994, p. 222-232. - (Obras escolhidas; v. 1)

. 1. ed, trad. Irene Aron e Cleonice Paes Barreto Mourão. Passagens. Belo Horizonte: Editora UFMG, 2009.

BENSE, Max. Sobre a literatura de Walter Benjamin. In: Revista USP, n. 15, 1992, p. $118-122$.

ECO, Umberto. Obra aberta: forma e indeterminação nas poéticas contemporâneas, trad. Giovanni Cutolo, São Paulo: Perspectiva, 1986.

GAGNEBIN, Jeanne Marie. Nas fontes paradoxais da crítica literária. Walter Benjamin relê os românticos de Iena. In: SELIGMANN-SILVA, Márcio (Org.). Leituras de Walter Benjamin. São Paulo: Annablume, 2007, p. 65-82.

1999.

. História e narração em Walter Benjamin. 2. ed. São Paulo: Perspectiva,

. Walter Benjamin ou a história aberta. In: BENJAMIN, Walter. Magia e técnica, arte e política: ensaios sobre literatura e história da cultura. 7. ed., trad. Sérgio Paulo Rouanet, São Paulo: Brasiliense, 1994, p. 7-20. - (Obras escolhidas; v. 1)

JAUSS, Hans Robert. Toward an Aesthetic of Reception. 1. ed, trans. Timothy Bahti. Minnesota: University of Minnesota Press, 1994.

Ática, 1994.

. A história da literatura como provocação à teoria literária. São Paulo:

KONERSMANN, Ralf. Bilder der Vergangenheit. In: . Erstarrte Unruhe: Walter Benjamins Begriff der Geschichte. Frankfurt: Fischer Taschenbuch, 1991, p. 6689.

Cadernos Benjaminianos, n. 3, Belo Horizonte, jan.-jun. 2011, p.1-13. 
MAN, Paul de. Introduction to Toward an Aesthetic of Reception. In: JAUSS, Hans Robert. BAHTI, Timothy (trans.). Toward an Aesthetic of Reception. Minnesota: University of Minnesota Press, 1994, p. VII-XXV.

ROUANET, Sergio Paulo. Apresentação. In: BENJAMIN, Walter. A origem do drama barroco alemão, trad. Sérgio Paulo Rouanet, São Paulo: Brasiliense, 1984, p. 11-47.

SELIGMANN-SILVA, Marcio. Ler o Livro do mundo. Walter Benjamin-Romantismo e Crítica poética. São Paulo: Iluminuras, 1999.

WITTE, Bernd. O que é mais importante: a escrita ou o escrito? In: Revista USP, n. 15, 1992. P. 85-89.

\section{Notas}

${ }^{1}$ GAGNEBIN. Walter Benjamin ou a história aberta, p. 12.

${ }^{2}$ JAUSS. A história da literatura como provocação à teoria literária, p. 24

${ }^{3}$ BENSE. Sobre a literatura de Walter Benjamin, p. 122.

${ }^{4}$ BENJAMIN. Origem do drama barroco alemão, p. 76-77.

${ }^{5}$ BENJAMIN. Origem do drama barroco alemão, p. 185.

${ }^{6}$ CREUZER apud BENJAMIN. Origem do drama barroco alemão, p. 186.

${ }^{7}$ BENJAMIN. Origem do drama barroco alemão, p. 182.

${ }^{8}$ GOETHE apud BENJAMIN. Origem do drama barroco alemão, p. 183.

${ }^{9}$ GAGNEBIN. História e narração em Walter Benjamin, p. 39.

${ }^{10}$ BENJAMIN. Origem do drama barroco alemão, p. 188.

${ }^{11}$ BENJAMIN apud WITTE. O que é mais importante: a escrita ou o escrito?, p. 87

${ }^{12}$ BENJAMIN. Origem do drama barroco alemão, p. 203-204.

${ }^{13}$ KONERMANN. Bilder der Vergangenheit, p. 66.

${ }^{14}$ BENJAMIN, 1984, p. 203.

${ }^{15}$ BENJAMIN, 1984, p. 201.

${ }^{16}$ BENJAMIN, 1984, p. 200.

${ }^{17}$ ROUANET. Apresentação, p. 39.

${ }^{18}$ GAGNEBIN, 1999, p. 44.

${ }^{19}$ WITTE. O que é mais importante: a escrita ou o escrito?, p. 88.

${ }^{20}$ BENJAMIN, 1984, p. 258.

${ }_{21}^{21}$ JAUSS, A história da literatura como provocação à teoria literária, p. 22.

22 JAUSS, A história da literatura como provocação à teoria literária, p. 20; grifo do autor.

${ }^{23}$ JAUSS. A história da literatura como provocação à teoria literária, p. 16.

${ }^{24}$ JAUSS, A história da literatura como provocação à teoria literária, p. 25; grifo meu.

${ }^{25}$ GADAMER apud JAUSS, A história da literatura como provocação à teoria literária, p. 40.

${ }_{26}$ JAUSS, A história da literatura como provocação à teoria literária, p. 49.

${ }^{27}$ JAUSS, A história da literatura como provocação à teoria literária, p. 48.

${ }^{28}$ JAUSS, A história da literatura como provocação à teoria literária, p. 57; grifo do autor.

${ }^{29}$ BENJAMIN, Origem do drama barroco alemão, p. 86.

${ }^{30}$ BENJAMIN, Origem do drama barroco alemão, p. 122.

${ }^{31}$ BENJAMIN, Origem do drama barroco alemão, p. 77. 
${ }^{32}$ BENJAMIN, Origem do drama barroco alemão, p. 89-90.

${ }^{33}$ BENJAMIN, Origem do drama barroco alemão, p. 90.

${ }^{34}$ BENJAMIN, Origem do drama barroco alemão, p. 68. 